
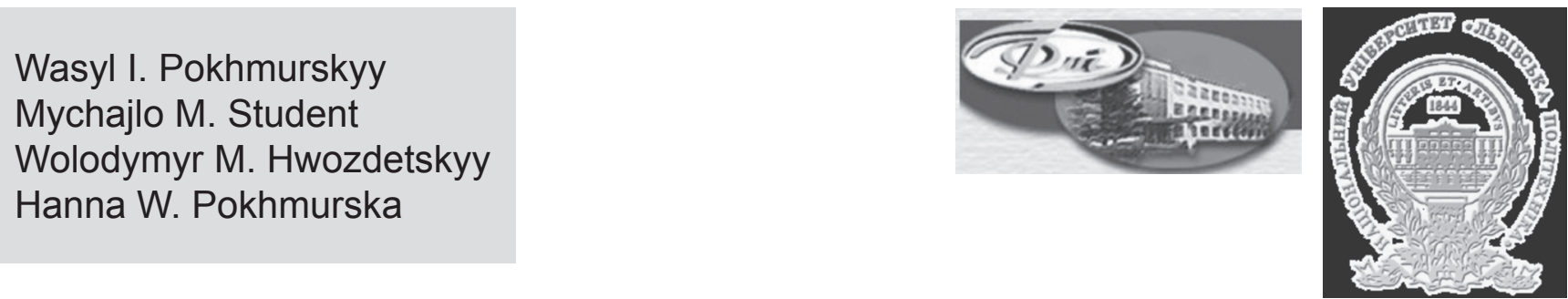

\title{
Druty rdzeniowe serii FMI do natryskiwania łukowego
}

\section{Powder wire of FMI series for electroarc spray coating}

\section{Streszczenie}

W artykule podano krótki opis opracowanych w Fizyczno-Mechanicznym Instytucie im. G.W. Karpienki Państwowej Akademii Nauk we Lwowie (FMI) drutów proszkowych (DP) do natryskiwania łukowego. Pokazano, że opracowanie i zastosowanie specjalnych drutów rdzeniowych (DR) jako materiałów elektrodowych poszerzyło zastosowanie elektrometalizacji. W wielu przypadkach pozwoliło to na uzyskanie powłok o właściwościach na poziomie najlepszych powłok natryskiwanych innymi metodami natryskiwania cieplnego, na przykład metodą plazmową albo naddźwiękową, przy zachowaniu znacznej przewagi ekonomicznej.

\section{Abstract}

In the present review of the brief description developed in G.V. Karpenko Physico-Mechanical Institute of National Academy of Sciences of Ukraine (FMI) arc spray wires. It is shown that development and using of new special arc spray wires as electrode materials, expanded of electrometallization applications. In many cases, it is possible to obtain a coating having the same characteristics as a top-level spray coatings obtained by using of other thermal spraying methods, e.g., plasma or supersonic methods, while maintaining economic advantages.

\section{Wstęp}

Natryskiwanie łukowe zostało opracowane prawie sto lat temu i jest jedną z metod natryskiwania cieplnego w celu powlekania rożnych detali. Ta metoda jest w porównaniu z innymi metodami najprostsza, najbardziej wydajna, nie wymaga drogiego sprzętu i można ją łatwo wdrożyć do produkcji. Przez dłuższy czas zasadniczą wadą tej metody był mały asortyment materiałów, ponieważ wykorzystywane były wyłącznie druty odlewane. Dlatego opracowanie drutów proszkowych (DP) jako natryskowych materiałów

Prof. dr hab. inż. Wasyl I. Pokhmurskyy, dr hab. inż. Mychajlo M. Student, prof. PLw, dr inż. Wolodymyr M. Hwozdetskyy Fizyczno-Mechaniczny Instytut im. G.W. Karpienki Państwowej Akademii Nauk we Lwowie, Ukraina; dr hab. inż. Hanna W. Pokhmurska, prof. PLw - Politechnika Lwowska, Ukraina.

pozwoliło w szerokich ramach zmieniać skład chemiczny powłok, co znacznie rozszerza zakres ich stosowania. W wielu przypadkach możliwe jest uzyskanie powłok o właściwościach porównywalnych z natryskiwanymi metodą plazmową czy naddźwiękową. Jednak koszt przy powlekaniu łukowym kształtuje się na poziomie

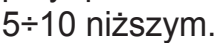

Na dzień dzisiejszy druty rdzeniowe (DR) do natryskiwania elektrołukowego produkowane są zarówno za granicą (firmy Metco, Castolin, TAFA, Nanosteel), jak i na Ukrainie. Największy wkład w rozwój natryskiwania drutami rdzeniowymi elektrołukowymi wnieśli specjaliści z Instytutu Elektrospawalnictwa im. Je.O. Patona Państwowej Akademii Nauk w Kijowie (Y.S. Borysow, A.L. Borysowa, W.N. Korzyk - drut rdzeniowy Amotek $[1 \div 4]$ ), Instytutu Hutniczego w Mariupolu (W.J. Royanow - drut PP-MM [5]) oraz Fizyczno-Mechanicznego Instytutu im. G.W. Karpienki Państwowej Akademii Nauk we Lwowie (W.I. Pokhmurskyy, M.M. Student 


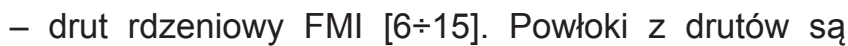
wykorzystywane w wielu gałęziach inżynierii, $\mathrm{np}$. do renowacji detali, jak również do ochrony przed ścieraniem i zużyciem ściernym i gazowym, w temperaturze pokojowej i podwyższonej do $700^{\circ} \mathrm{C}$ do naprawy różnych części maszyn i detali, pracujących w warunkach smarowania granicznego.

W Fizyczno-Mechanicznym Instytucie im. G.W. Karpienki Państwowej Akademii Nauk we Lwowie opracowano druty proszkowe o średnicy $1,8 \mathrm{~mm}$ do natryskiwania elektrołukowego (tabl. I). Partie pilotażowe produkowane są w Instytucie Elektrospawalnictwa im. Je.O. Patona Państwowej Akademii Nauk w Kijowie. Wyniki badań na temat rozwoju drutów proszkowych, w tym oceny ich mikrostruktury i właściwości do różnych celów i zastosowań przedstawiono w pracach $[6 \div 12]$. Opracowane składy chemiczne drutów prosz-

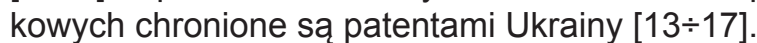

\section{Rozwój powłok z drutów proszkowych}

Renowacyjne powłoki stosowane są do naprawy zużytych powierzchni części, np. takich jak wały z wymaganą kolejną obróbką mechaniczną, głównie za pomocą skrawania. Dlatego dla takich powłok najbardziej istotna jest ich wysoka odporność na ścieranie oraz obrabialność przy obróbce mechanicznej. Warunki te są przewidziane przy tworzeniu powłok z twardością, która osiagga $300 \div 400 \mathrm{HV}$, a w ich strukturze występuje minimalna zawartość fazy tlenowej.
Minimalną zawartość tlenu w powłoce - na poziomie $2 \%$ mas., zapewnia się $w$ mieszaninie przy obecności w proszku na drut rdzeniowy węgla $-0,8 \%$, chromu $-6 \%$, aluminium $-6 \%$ (rys. 1 ).

Wraz ze wzrostem zawartości aluminium zmniejsza się ilość martenzytu, lecz wzrasta zawartość ferrytu w powłoce. W tym przypadku twardość powłoki zmniejsza się, przy jednoczesnym wzroście jej wytrzymałości adhezyjnej. Optymalną twardość powłoki - w zakresie 300 $\div 400$ HV uzyskuje się przy obecności w drucie rdzeniowym $6 \div 12 \%$ mas. aluminium. Fazą matrycowa (osnowa) takiej powłoki jest stopowany chromem i aluminium ferryt. DP ze zwiększoną a)

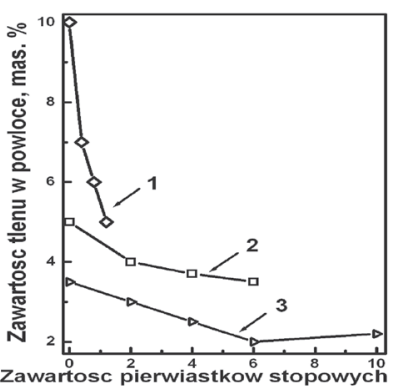

w DP, mas. \% b)

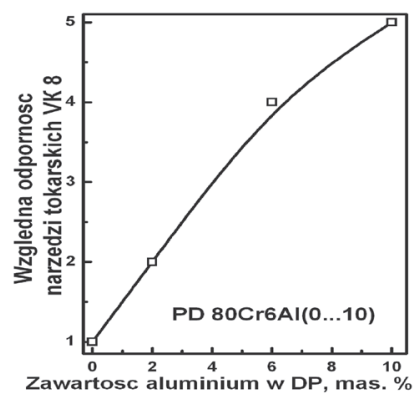

Rys. 1. Wpływ ilości węgla, chromu i aluminium w proszku do PD na zawartość tlenu w powłoce (a) oraz względna odporność narzędzia tokarskiego ze stopu VK8 (b) przy obróbce powłok 80H6Al PD (0 .. 10): 1 - węgiel, 2 - DP $80 \mathrm{Cr}(0 \ldots 6), 3$ - DP $80 \mathrm{Cr} 6 \mathrm{Al}(0 \ldots 10)$ Fig. 1. Influence of amount of carbon, chromium and aluminum in the power for $\mathrm{CW}$ on the amount of oxygen in the coating (a) and the relative resistance of lathe instrument from the alloy VK8 (b) at the treatment pf coating $80 \mathrm{H} 6 \mathrm{Al} \mathrm{PD}(0$.. 10): 1 - carbon, 2 - CW $80 \mathrm{Cr}(0 \ldots 6), 3-\mathrm{CW} 80 \mathrm{Cr} 6 \mathrm{Al}(0 \ldots 10)$

Tablica I. Druty rdzeniowe i ich zastosowanie Table I. Flux cored wires and their application

\begin{tabular}{|c|c|c|c|}
\hline $\begin{array}{c}\text { Gatunek } \\
\text { drutu }\end{array}$ & System stopowania & $\begin{array}{c}\text { Właściwości powłok } \\
\text { HRC, HV, } \\
\text { wytrzymałość kohezyjna } \\
\text { i adhezyjna }\end{array}$ & Zastosowanie \\
\hline FMI-2 & Cr6Al8B3 & $\begin{array}{l}\text { HRC }=40 \\
\text { HV }=650 \\
\text { Wytrzymałość: } \\
\text { - kohezyjna }=130 \mathrm{MPa} \\
\text { - adhezyjna }=40 \mathrm{MPa}\end{array}$ & $\begin{array}{c}\text { Renowacje szyjek średnio obciążonych wałów } \\
\text { korbowych, rozrządu, ochrona przed zużyciem } \\
\text { abrazyjnym sprzętu poligraficznego }\end{array}$ \\
\hline FMI -5 & 50Cr6Al3Mn2Mo2C2 & $\begin{array}{l}\text { HV }=350 \\
\text { Wytrzymałość: } \\
\text { - kohezyjna }=180 \mathrm{MPa} \\
\text { - adhezyjna }=40 \mathrm{MPa}\end{array}$ & Renowacja części łożysk \\
\hline FMI -6 & Cr6Al6B3Ni4 & $\begin{array}{l}\text { HRC }=40 \\
\text { HV }=1000 \\
\text { Wytrzymałość: } \\
\text { - kohezyjna = } 60 \mathrm{MPa} \\
\text { - adhezyjna }=45 \mathrm{MPa}\end{array}$ & $\begin{array}{l}\text { Ochrona przed zużyciem ścierno-gazowym } \\
\text { i korozją gazową w wysokiej temperaturze }\left(700^{\circ} \mathrm{C}\right)\end{array}$ \\
\hline FMI -7 & 70Cr6Al6B3W4 & $\begin{array}{l}\text { HRC }=40 \\
\mathrm{HV}=1150 \\
\text { Wytrzymałość: } \\
\text { - kohezyjna = } 120 \mathrm{MPa} \\
\text { - adhezyjna }=45 \mathrm{MPa}\end{array}$ & $\begin{array}{l}\text { Ochrona przed zużyciem ścierno-gazowym } \\
\text { i korozją gazową w wysokiej temperaturze }\left(600^{\circ} \mathrm{C}\right)\end{array}$ \\
\hline FMI -8 & 50Cr6Al2Mn2Ti2Mo2 & $\begin{array}{l}\text { HV }=500 \\
\text { Wytrzymałość: } \\
\text { - kohezyjna }=180 \mathrm{MPa} \\
\text { - adhezyjna }=40 \mathrm{MPa}\end{array}$ & $\begin{array}{l}\text { Renowacje szyjek, średnio obciążonych } \\
\text { wałów korbowych i rozrządu }\end{array}$ \\
\hline
\end{tabular}


ilością aluminium były wykorzystywane w energetyce przy renowacji miejsc osadzenia wałów wirników silników elektrycznych, bębnów hamulcowych samochodów ciężarowych itp. (rys. 2).

Dla powłok stosowanych do części działających w warunkach ścierania przedstawia się następujące wymagania: wysoka twardość, niski poziom naprężeń 1. rodzaju i wysoka odporność na ścieranie.
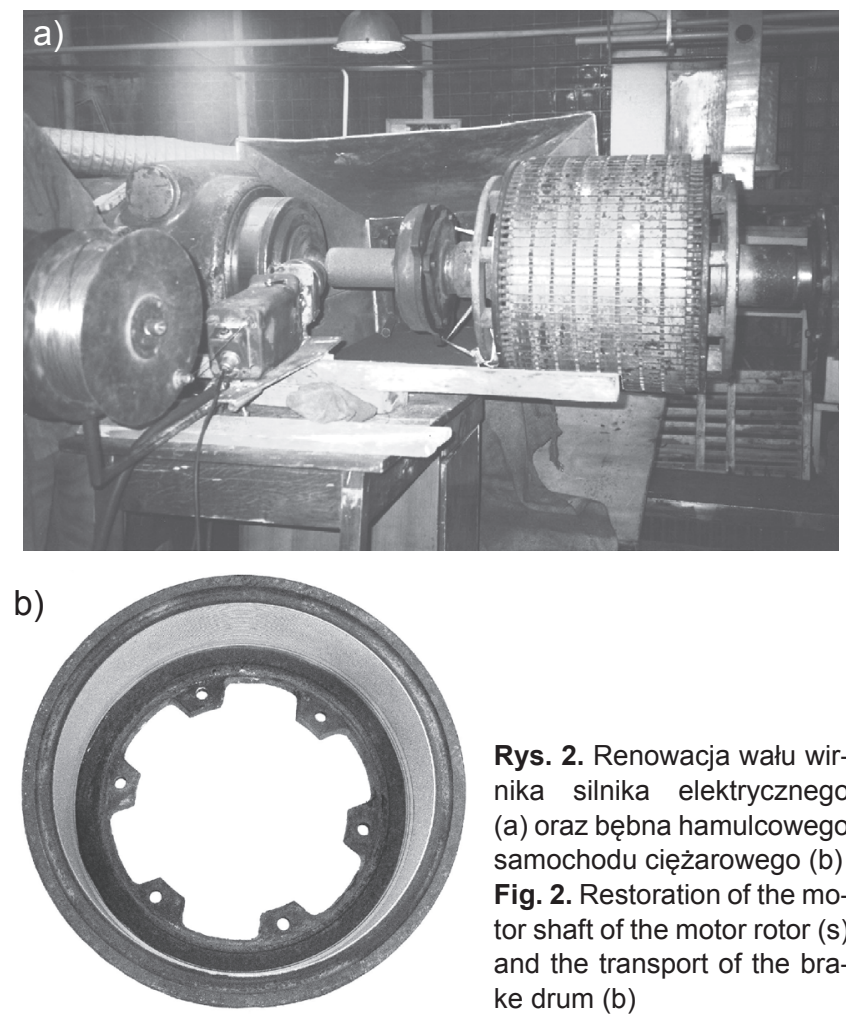

Rys. 2. Renowacja wału wirnika silnika elektrycznego (a) oraz bębna hamulcowego samochodu ciężarowego (b) Fig. 2. Restoration of the motor shaft of the motor rotor (s) and the transport of the brake drum (b)

Okazuje się, że przy zwiększeniu twardości powłok do 700 $\div 800 \mathrm{HV}$ ich odporność na ścieranie wzrasta, a przy twardości większej niż $800 \mathrm{HV}$ - zmniejsza się, co jest związane z tworzeniem i występowaniem mikropęknięć w powłoce. Zużycie powłoki odbywa się względem istniejących pęknięć, głównie na granicach ziarn z późniejszym rozszczepieniem się i naruszeniem spójności. Stwierdzono, że odporność powłoki na zużycie przy badaniach ścierniwem zapewnia twardsze ziarna i twarde tlenki glinu na granicach pomiędzy ziarnami. W związku z tym w tym przypadku powinna być utworzona powłoka, z jednej strony, z wysoką mikroheterogennością, co zapewnia niski poziom naprężeń rozciągających, a z drugiej, z małą grubością warstwy (powłok o wysokiej dyspersji), aby zwiększyć zawartość tlenków w granicach międzyziarnowych.

W badaniach ścierniwem występują odcinki powłok o niskich właściwościach, gdzie obserwowane są ziarna o najniższej twardości i granicy międzyziarnowej. W tym przypadku trzeba wytworzyć powłokę o niskiej i mikroheterogenności i maksymalnej grubości ziarn w celu zminimalizowania liczby granic międzyziarnowych. Powłoki systemu Fe-Cr-B-Al marek PMI są szeroko stosowane do ochrony przed ścieraniem w przemyśle drukarskim (rys. 3).

\section{Powłoki dla elementów pracujących w warunkach granicznego tarcia}

Twardość tych powłok musi być nie niższa niż 600 HV. Ich obróbka mechaniczna odbywa się przez szlifowanie do wymaganego wymiaru. W strukturze powłoki często mają miejsce mikropęknięcia, które mogą doprowadzić do zniszczenia powłoki podczas eksploatacji. W celu zapewnienia wymaganych cech do proszku dla powłoki są wprowadzone chrom, węgiel, bor i aluminium $w$ takich ilościach, aby fazą matrycową powłoki był martenzyt. Taka struktura zapewnia minimalny poziom naprężeń rozciągających w powłoce, nie więcej niż $50 \mathrm{MPa}$.

Przy względnych obciążeniach większych niż $14 \mathrm{MPa}$ w parze tarcia powłoka-przeciwpróbka następuje się katastrofalne zużycie przeciwpróbki. Analiza metalograficzna i rentgenowska umożliwiła ustalenie, że jest to skutkiem obecności pęknięć na powierzchni powłok. Wówczas następuje otwarcie brzegów - powstają karby, które działają jak noże. Odległości pomiędzy pęknięciami wynoszą do 0,3 $\mu \mathrm{m}$ i utworzone są z tlenków aluminium i węglików. Ustalono, że pęknięcia z węglików na powierzchni szlifowanej powłok są tworzone przez częściowe rozpuszczenie dużych węglików ze stopionego drutu rdzeniowego.

Aby wyeliminować intensywne zużycie przeciwpróbki w parze tarcia z powłoką, zaproponowano metody optymalizacji powłok, które sprowadzają się do następujących czynności:

1. Zapewnienia warunków zabezpieczających rozpuszczenie węglików w stopie drutu rdzeniowego za pomocą wykorzystania mniejszego rozmiaru węglików w mieszaninie DP lub stosowania większego napięcia łuku przy natryskiwaniu $(34 \div 38 \mathrm{~V})$;

2. Zmniejszenia zawartości powietrza $w$ proszku DP przez jego zgniecenie i dodanie proszku zawierającego
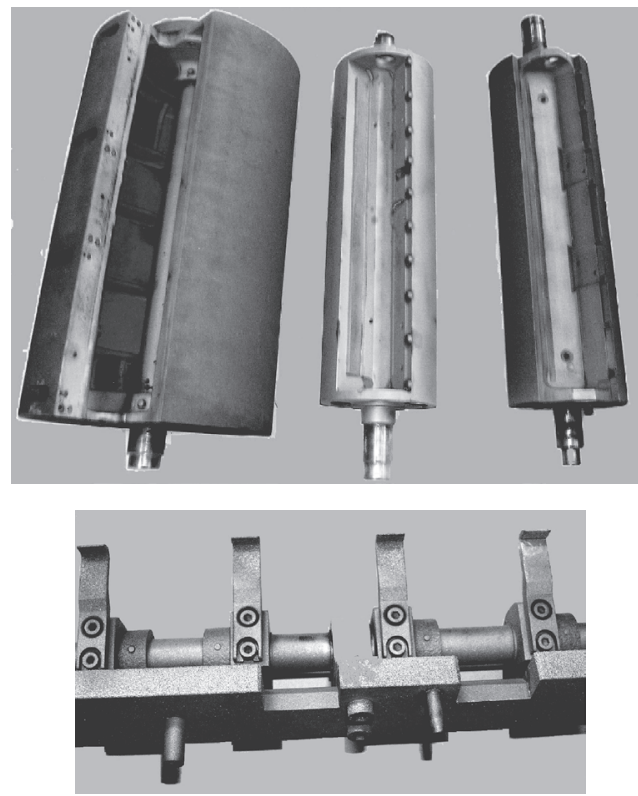

Rys. 3. Regenerowane części maszyn drukarskich Fig. 3. Refurbished parts of printing machines 
związek tytanu, który powoduje zajście reakcji w fazie gazowej $\mathrm{z}$ tlenem $\mathrm{w}$ stopionej strefie, tworząc małe

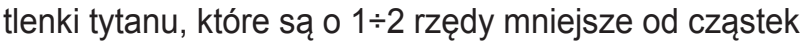
$\mathrm{Al}_{2} \mathrm{O}_{3}$.

$\mathrm{Na}$ wypolerowanej powierzchni powłoki uzyskanej z DP nie znaleziono mikropęknięć, a i chropowatość jej polerowanej powierzchni jest zasadniczo mniejsza. Ponadto, tytan i magnez w składzie drutu rdzeniowego powodują wchłanianie $2 \div 3 \%$ mas. azotu z powietrza, zawartego w porach proszku, dzięki czemu w powłoce tworzone są cząstki azotków tytanu o wymiarach $200 \div 500 \mathrm{~nm}$.

Dzięki strukturze nierównowagowej i składowi fazowemu powłok przy tarciu mogą być realizowane warunki sprzyjające samoorganizacji warstwy powierzchniowej.

Metodami niskokątowych badań rentgenowskich stwierdzono, że warunki optymalne dla samoorganizacji powierzchni tworzą się w powłoce trzyfazowej z fazą matrycową, składającą się z martenzytu ( 50\%), austenitu ( 30\%) i ferrytu ( 20\%). Przy wysokich obciążeniach tarcia $\mathrm{z}$ austenitu wydzielają się węgliki $(\mathrm{Fe}, \mathrm{Cr})_{23} \mathrm{C}_{6}$, a część jest przekształcona w martenzyt odpuszczony przy pochłanianiu ciepła.

W ferrycie wydzieliły się nanocząsteczki grafitu $(10 \div 20 \mathrm{~nm})$. Przy tarciu węgiel dyfunduje na powierzchnie tarcia i tworzy ciągłe warstwy grafitu. Optymalna zawartość ferrytu w strukturze powłoki wynosi 10 $\div 20 \%$ mas. Minimalny współczynnik tarcia i zużycia pary ciernej przedstawiono na rysunkach 4 i 5 . Taka zawartość ferrytu w powłoce jest zapewniona dzięki obecności w nich $2 \div 3 \%$ mas. aluminium.

DP serii FMI zostały wykorzystane do renowacji powlekaniem natryskowym szyjki wału turbiny i sprężarki wałów pomp gazowych w przedsiębiorstwach naprawczych Ukrgazenergoservis, a także prętów siłowników hydraulicznych urządzeń górniczych (rys. 6).

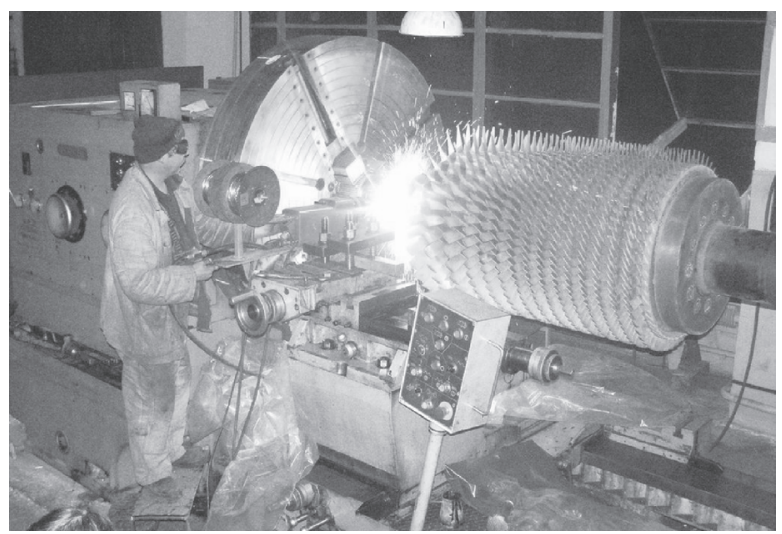

Rys. 6. Powlekanie natryskowe szyjki wału turbiny

Fig. 6. Spray coating on the turbine shaft bearing neck

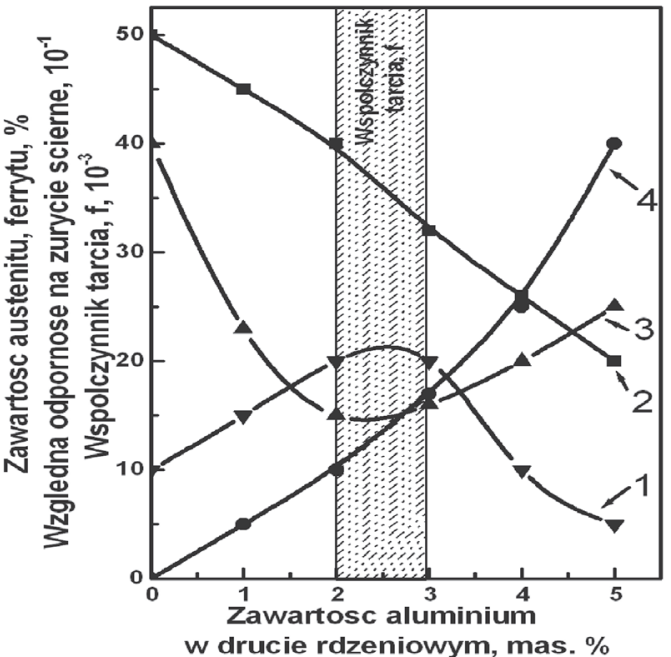

Rys. 4. Wpływ zawartości aluminium w DP 50Ni6Ti2Mo2Al2 na właściwości trybologiczne powłok ze strukturą trójfazową w warunkach smarowania granicznego przy względnym obciążeniu P = 7 MPa: 1 - austenit, 2 - ferryt, 3 - współczynnik tarcia, 4 - względna trwałość. Fig. 4. Effect of aluminum content in PD50Ni6Ti2Mo2Al2 the tribological properties of the coating design phase boundary lubrication conditions in a particular load P = $7 \mathrm{MPa}$ : 1 - austenite, 2 - ferrite, 3 - coefficient of friction, 4 - relative hardness.

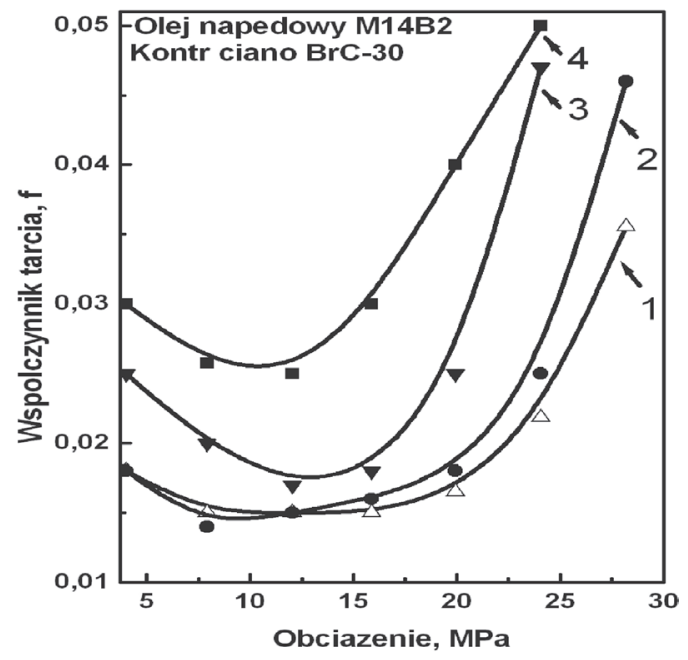

Rys. 5. Zmiana współczynnika tarcia M14B2 w oleju napędowym w zależności od określonego obciążenia dla węzłów tarcia powłoki z DP brąz (BrC-30): 1 - 50Cr6AITi2; 2 - 50Cr6AITi2+Cr6AI6B3; 3 - stal SzKh 15, HRC 62; 4 - Cr6Al6B3

Fig. 5. The coefficient of friction M14B2 in oil, depending on the specified load to the friction parts with the CW - bronze (BrC-30): 1 - 50Cr6AITi2; 2 - 50Cr6AITi2+Cr6AI6B3; 3 - steel SzKh 15, HRC 62; 4 - Cr6Al6B3

\section{Wnioski}

Pokazano, że opracowanie i zastosowanie specjalnych drutów rdzeniowych (DR) jako materiałów elektrodowych poszerzyło zastosowanie elektrometalizacji. W wielu przypadkach pozwoliło to na uzyskanie powłok o właściwościach na poziomie najlepszych powłok natryskiwanych innymi metodami natryskiwania cieplnego, na przykład metodą plazmową albo naddźwiękową, z zachowaniem przy tym znacznej przewagi ekonomicznej. 


\section{Literatura}

1] Borysow Y.S., V.N. Korzhik. Amorficzne powłoki gazo termiczne: teoria i praktyka. Spawanie automatyczne. 1995. N 4. $s .3 \div 12$

[2] Borisowa A.L., I.V. Myts, T. Kaida. Struktura i własności powłok elektro lukowych na osnowie borku żelaza otrzymanych z drutów proszkowych. - Spawanie automatyczne. 1991. N 9. s. $66 \div 68$.

[3] Borysow Y.S., I.A. Koziakov, V.N. Korzhik. Struktura i właściwości gazo termicznych powl, otrzymanych przy użyciu drutów proszkowych systemów Fe-Cr-B, Fe-Cr-B-C. - Spawanie automatyczne. 1996. N 5. S. 21 - 24.

[4] Borisov Y.S., A.L. Borisova, I.A. Koziakov. Wpływ warunków natryskiwania na struktury powłok, otrzymanych z drutu proszkowego „Amotek 101”. Spawanie automatyczne. 1996. N 1. S. 21 - 30.

[5] Royanov V.A. Podstawy teoretyczne tworzenia i wdrodzenia przemysłowego ekonomno stopowanych drutów proszkowych dla natryskiwania elektro lukowego powłok, odpornych na ścieranie z polepszonymi właściwościami eksploatacionnymi.- Praca habilitacyjna doktora nauk technicznych. Mińsk, 1990. 36 str.

[6] Pokhmurskii V.I., M.M.Student, V.M. Dovhunyk, G.V. Pokhmurska, I.I. Sydorak. Powłoki elektro lukowe dla renowacji i ochrony. Lwow: Fizyko-Mechaniczny Instytut imienia G.W.Karpienki Państwowej Akademii Nauk we Lwowie, 2005. - 190 str.

[7] Pokhmurskii V.I., M.M. Student, V.M. Dovhunyk, I.I. Sydorak Zastosowanie metalizacji elektro lukowej drutami proszkowymi systemu Fe-Cr-Al-C dla renowacji detali maszyn . Maszynoznawstwo. 1999. N 1. S. 13-18.

[8] Student M. M., V. M. Dovhunyk, I. I. Sydorak, H. V. Pokhmurs'ka. Effect of Friction on Phase Transitions in the Surface Layers of FeCrB + Al Gas-Thermal Coatings.- Materials Science (Springer). 2000. No 4.- P.607-611.

[9] Dovhunyk V. M., M. M. Student, I. I. Sydorak, H. V. Pokhmurs'ka Effect of Friction on the Structural and Phase Transformations in the Subsurface Layer of a $\mathrm{FeCr}+\mathrm{Al}+\mathrm{C}$ GasThermal Coating.- Materials Science (Springer). 2000. No 5. s. $770 \div 775$.

[10] Tribologycal properties of arc sprayed coatings obtained from $\mathrm{FeCrB}$ and $\mathrm{FeCr}$ based powder wires, A. Pokhmurska, M. Student, E. Bielanska, E.Beltowska, V. Dovhunyk, Surface \& Coating Technology. 2002. V. 151-152. s. 490 $\div 494$.
[11] Triboelektrochemiczne właściwości powlekanie natryskiwanych łukowo na stopy aluminium, V. Pokhmurskii, V. Dovhunyk, M. Student, H. Pokhmurska, V. Vynar, I. Sydorak, Inży-

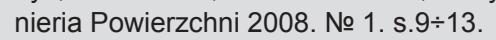

[12] Student M., Yu. Dzioba, V. Hvozdets'kyi, H. Pokhmurs'ka, B. Wielage. High-temperature corrosion of electric-arc coatings sprayed from powder core wires based on the $\mathrm{Fe}-$ Cr-B-Al system.- Materials Science (Springer). 2008. No 5. s.693 $\div 699$.

[13] Pat. N 40722 Ukraina, IPC (2009) S23S 4/00, B22F 7/00, B32B 15/00. Druty rdzeniowe do otrzymywania powłok dyspersyjnie wzmocnionych / V.I.Pohmurskyy, M.M.Student, Yu.V.Dzoba, I.Y.Sydorak; FMI Narodowej Akademii Nauk Ukrainy. - U2008 12843; PDI. 11.03.2008, wyd. 27.04.2009, Bull. Numer 8.

[14] Pat. N 40723 Ukraina, IPC (2009) S23S 4/00, B22F 7/00, B32B 15/00. Druty rdzeniowe do otrzymania powłok, M.M.Student, H.V.Pohmurska Ya.Ya.Sirak, V.M.Hvozdetskyy. FMI Narodowej Akademii Nauk Ukrainy. U2008 12844; PDI. 11.03.2008, wyd. 27.04.2009, Bull. Numer 8.

[14] Pat. N 47456 Ukraina, IPC (2009) S23S 6/00. Druty rdzeniowe do elektro lukowego natryskiwania w wysokiej temperaturze dyspersyjne wzmocnione, V.I.Pohmurskyy, M.S.Romaniv, M.M.Student, H.V.Pohmurska, T.M.Harandyuk, Ya.V.Serivka; FMI Narodowej Akademii Nauk Ukrainy, Bursztyn TPD. U2009 05524; aPDI. 06.01.2009, wyd. 10.02.2010, Bull. Numer 3.

[15] Pat. N19967 Ukraina, IPC (2006) S23S 4/00. Sposób wytwarzania powłok kompozytowych, S.I.Markovych, V.I.Pohmurskyy, O.Y.Mazheyko, M.M.Student; FMI Narodowej Akademii Nauk Ukrainy, Kirovograd Narodowy Uniwersytet Techniczny. - U2006 05358; PDI. 16/05/2006, wyd. 15.01.2007, Bull. Numer 1.

[16] Pat. № 20013 Ukraina, IPC (2006) S23S 4/04, S23S 4/12. Druty rdzeniowe do ochrony od gorącego gazu dla otrzymania powłok kompozytowych, V.I.Pohmurskyy, H.V.Pohmurska, M.M.Student, Yu.V.Dzoba, Ya.Ya.Sirak/ FMI Narodowej Akademii Nauk Ukrainy. U2006 06217; PDI. 06.05.2007, wyd. 15.01.2007, Bull. Numer 1.

[17] Pat. № 40721 U Ukraina, IPC (2009) S23S 4/00, B22F 7/00, B32B 15/00. Druty rdzeniowe do elektro lukowego natryskiwania, V.I.Pohmurskyy, M.M.Student, Yu.V.Dzoba, I.Y.Sydorak; FMI Narodowej Akademii Nauk Ukrainy. - U2008 12842; PDI. 11.03.2008, wyd. 27.04.2009, Bull. Numer 8. 